\title{
PERMUKIMAN EMPLASEMEN PABRIK GULA PURWOREJO (1910-1933)
}

\section{PURWOREJO SUGARCANE EMPLACEMENT SETTLEMENTS (1910-1933)}

\author{
Lengkong Sanggar Ginaris \\ Mahasiswa S2 IImu Arkeologi, Fakultas IImu Budaya \\ Universitas Gadjah Mada \\ Lengkong.sanggar.g@ugm.ac.id
}

\begin{abstract}
One of the sugar industries in Java is PG Purworejo, which was built in 1910. Near the PG Purworejo emplacement, there are settlements for factory employees. Although there have been many archeological studies about sugar mills, but deeper study of the existence of employee settlements still few. This study aims to reconstruct the PG Purworejo emplacement settlement from 1910 to 1930. The data used in this research is in the form of all material objects or physical data left from PG Purworejo and other related data such as old archives and photos. Data that has been collected and selected, then will be decrypted, processed to be identified and then interpreted based on the theoretical framework. Altough the remains of PG Purworejo's emplacement settlements is low, but the settlement layout can still be traced based on old photo data. The results of this study show that the emplacement settlement of PG Purworejo uses the concept of industrial settlements, where employee settlements are built near industrial sites. In addition to the concept of industrial cities, the concept of colonial settlements was also applied which was marked by the separation between European workers' settlement blocks and indigenous workers.
\end{abstract}

Keyword : Sugar Cane Plantation, Industrial Revolution, Industrial Settlement, Segregation, Spatial Planning.

\section{ABSTRAK}

Salah satu industri gula paling besar di Jawa adalah PG Purworejo yang dibangun tahun 1910an. Di dekat emplasemen PG Purworejo, terdapat permukiman untuk pegawai pabrik. Meski sudah banyak kajian arkeologi mengenai pabrik gula, namun kajian yang lebih dalam mengenai keberadaan permukiman pegawai pabrik gula masih belum banyak dilakukan. Penelitian ini bertujuan untuk merekonstruksi kembali permukiman emplasemen PG Purworejo dari tahun 1910 hingga 1930 serta konsep apa yang dipakai serta latar belakangnya. Data yang digunakan dalam penlitian ini berupa segala benda material atau data fisik yang ditinggalkan dari PG Purworejo serta data lain yang terkait seperti arsip dan foto lama. Data yang telah terkumpul dan terseleksi, berikutnya akan dideskripsi, diolah guna dikenali cirinya dan kemudian diintepretasikan berdasarkan kerangka teori. Berdasarkan hasil pengamatan di lapangan, bukti fisik permukiman emplasemen PG Purworejo tinggal berupa struktur pondasi dan satu bangunan rumah tinggal. Sedikitnya sisa dari PG Purworejo disebabkan karena pada tahun 1933 PG Purworejo ditutup akibat krisis malaise dan bangunan pabrik beserta permukiman pegawainya ikut dibongkar. Meskipun demikian tata ruang permukimannya masih dapat ditelusuri berdasarkan data foto lama. Hasil kajian menunjukan bahwa permukiman emplasemen PG Purworejo memakai konsep permukiman industri, dimana permukiman pegawai dibangun di dekat lokasi perindustrian. Selain konsep kota industri, konsep permukiman kolonial juga diterapkan pada permukiman emplasemen PG Purworejo yang ditandai dengan pemisahan antara blok permukiman pekerja Eropa dengan pekerja pribumi.

Kata Kunci : Perkebunan Tebu, Revolusi Industri, Permukiman Industri, Segregasi, Tata Ruang.

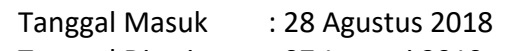




\section{PENDAHULUAN}

Permukiman telah menjadi salah satu kebutuhan dasar manusia sejak manusia mampu menghasilkan makanan sendiri dengan cara bercocok tanam dan domestifikasi hewan karena dengan demikian manusia tidak perlu berpindah untuk mencari sumber makanan. Perkembangan ilmu pengetahuan, keterampilan, serta pertambahan jumlah manusia menjadikan permukiman semakin kompleks seperti pendapat yang dikemukakan oleh Robert L. Carneiro. la berpendapat peningkatan jumlah penduduk diikuti dengan kemajuan teknologi, khususnya di bidang pertanian. Kemajuan teknologi di bidang tersebut berdampak dengan meningkatnya jumlah hasil pertanian. Pada saat hasil pertanian telah mencapai angka surplus, manusia akhirnya memiliki waktu luang dan memanfaatkannya untuk mengembangkan usaha lain, sehingga terciptalah spesialisasi kerja (Carneiro, 1970; 733-738). Kehidupan manusia semakin kompleks seiring dengan perkembangan teknologi.

$$
\text { Salah satu puncak }
$$

perkembangan teknologi yang berpengaruh pada peradaban manusia adalah Revolusi Industri yang dimulai di Inggris pada 1760. Revolusi Industri dimulai dari penemuan mesin uap oleh Thomas Savery yang kemudian disempurnakan oleh James Watt telah merubah wajah industri di Inggris. Kegiatan industri yang semula bergantung pada tenaga alam, hewan, atau manusia telah digantikan oleh mesin yang dapat menghasilkan suatu produk lebih banyak dalam waktu singkat. Melalui kolonialisasi, Revolusi Industri kemudian menyebar ke seluruh dunia tak terkecuali dengan Indonesia yang saat itu menjadi wilayah koloni Belanda. Pertumbuhan industri di Indonesia mulai berkembang setelah diberlakukannya Undang-Undang Agraria pada 1870, dimana pemerintah kolonial memutuskan untuk menyerahkan produksi kepada pengusaha swasta. Pada konteks yang lebih luas, pertumbuhan industri berdampak dengan munculnya kotakota industri di Hindia-Belanda seperti Sawah Lunto. Adanya kegiatan eksploitasi batu bara dalam bentuk tambang memberi efek yang signifikan terhadap wilayah Sawah Lunto. Para pekerja dari luar Sawah Lunto didatangkan dan kemudian diikuti dengan pembangunan infrastruktur pendukung di sekitar pusat industri seperti kantor, gereja, gedung societeit, rumah sakit, sekolah, pasar, permukiman pekerja, pembangkit listrik, stasiun dan gudang ransum (Sari, 2012; 70).

Salah satu industri yang paling berkembang pesat di Indonesia adalah industri gula (Cribb dan Kahin, 2012; 520). Perkembangan industri gula di Indonesia didukung oleh ketersediaan tenaga buruh yang murah serta pemilihan pangsa pasar yang tepat (Knight, 1999; 98). Penggunaan teknologi modern dan besarnya perhatian investor swasta juga memberi sumbangsih dalam kemajuan industri gula (Sulastri, 2006; 10). Pada 1930, tercatat ada 178 pabrik gula di Jawa dan setiap pabrik biasanya memiliki luas perkebunan sekitar 1.100 hektar. Tanaman tebu merupakan tanaman yang membutuhkan kondisi pertanian yang sama dengan padi dengan volume air yang lebih banyak jumlahnya serta tenaga kerja yang berpengalaman. Oleh karena itulah 
perkebunan tebu dibuka di wilayah dataran rendah yang sudah lama menanam padi (Stroomberg, 2018; 185-189). Salah satu perkebunan tebu yang dibuka oleh Belanda di Jawa adalah Suikeronderneming Poerworedjo, yang dibuka pada tahun 1910an. Perkebunan tebu tersebut memiliki sebuah emplasemen ${ }^{1}$ pabrik gula yang dikenal dengan nama Suikerfabriek Poerworedjo

Keberadaan PG Purworejo disebutkan dalam catatan Belanda di Purworejo, salah satunya adalah tulisan Becking dalam majalah Indie, geilustreerd weekblad voor Nederland en Kolonien no.47 tanggal 21 Februari 1923, yang berjudul "Eene Beshcriving van Poerworedjo en Omstreken ". Dalam tulisan tersebut, dipaparkan bahwa di selatan kota Purworejo, terdapat sebuah kompleks pabrik gula yang besar milik Suikerfabriek Poerworedjo. Namun tulisan Becking tidak memberi gambaran secara rinci mengenai permukiman pegawai di emplasemen pabrik gula tersebut (Becking, 1923;740).

Kajian arkelogi mengenai

permukiman, utamanya di lingkungan pabrik gula sudah banyak dilakukan, misalnya adalah tesis penelitian Hari Libra Inagurasi yang mengkaji Pabrik Gula Cepiring, Kendal. Selain membahas proses produksi gula di PG Cepiring, Inagurasi dalam penelitiannya bejudul Pabrik Gula Cepiring di Kendal Jawa Tengah Tahun 18351930, Sebuah Studi Arkeologi Industri menjelaskan bahwa Pabrik Gula Cepiring memiliki segregasi dalam pengelompokan bangunan berdasarkan pada golongan yang terdapat pada masyarakat lingkungan pabrik gula. Pemisahan tersebut menunjukan adanya perbedaan tingkat antara pemimpin pabrik dengan pegawainya.

Permukiman emplasemen pabrik gula dibahas secara mendalam oleh van Moll dan Lugten dalam buku Projecten voor Suikerondernemingen yang diterbitkan tahun 1916. Dalam buku itu, van Moll dan Lugten memberi panduan kepada pemilik pabrik seperti apa idealnya bentuk sebuah permukiman emplasemen pabrik gula. Dijelaskan bahwa permukiman emplasemen pabrik gula yang baik adalah permukiman yang dapat menyediakan segala sarana untuk para pegawainya, baik untuk pegawai Eropa atau pegawai pribumi. Sarana itu meliputi air bersih, saluran pembuangan, jaringan listrik, lampu jalan, sosieteit, dan klinik kesehatan. Dengan segala fasilitas tersebut, maka kesejahteraan sosial, fisik, dan mental pegawai bisa meningkat sehingga berdampak pada peningkatan produktivitas. Sebagaimana emplasemen pabrik gula di Jawa, emplasemen pabrik gula Purworejo selain dibangun untuk tujuan produksi juga dilengkapi dengan permukiman yang memberikan kenyamanan bagi pemukimnya. Bila dibandingkan dengan permukiman industri di Sawah Lunto, permukiman emplasemen pabrik gula Purworejo memiliki kemiripan seperti adanya kompleks permukiman pekerja yang

${ }^{1}$ Emplasemen adalah tempat terbuka atau tanah lapang yang disediakan untuk suatu bangunan (Inagurasi, 2010; 152). 
dekat dengan kegiatan industri, hanya saja sarana dan prasarana yang ada tidak selengkap yang ada di Sawah Lunto.

Tujuan penelitian Arkeologi mencakup tiga hal, yakni menyusun kronologi budaya, rekonstruksi cara hidup, dan/atau penggambaran proses budaya (Fagan, 1991; 44). Berdasarkan landasan tersebut, penelitian ini bertujuan untuk merekonstruksi konsep yang digunakan dalam penataan emplasemen pabrik gula. Menyangkut keberadaan permukiman tersebut terdapat permasalahan yaitu konsep apa yang digunakan dalam permukiman emplasemen Pabrik Gula Purworejo dan mengapa konsep tersebut dipilih.

\section{METODE}

Penelitian ini akan mengkaji emplasemen Pabrik Gula Purworejo yang terletak di Dukuh Mbabrik, Desa Plandi, Kecamatan Purwodadi, Kabupaten Purworejo. Dalam mengungkap permukiman emplasemen Pabrik Gula Purworejo, data yang digunakan adalah data arkeologi berupa segala bendabenda material atau data fisik yang ditinggalkan dari aktivitas tersebut. Data fisik yang akan dikumpulkan berupa bangunan tempat tinggal dan sisa-sisanya. Data ini dikumpulkan melalui observasi lapangan. Karena bangunan Pabrik Gula Purworejo dan rumah di emplasemen ini sudah menghilang, maka selain melakukan observasi lapangan, data arsitektur akan diambil melalui foto-foto kuna. Data arkeologi yang telah terkumpul dan terseleksi, berikutnya akan dideskripsi, diolah guna dikenali cirinya. Data fisik tersebut kemudian diintegrasikan dengan data lain seperti foto kuna. Dalam rangka

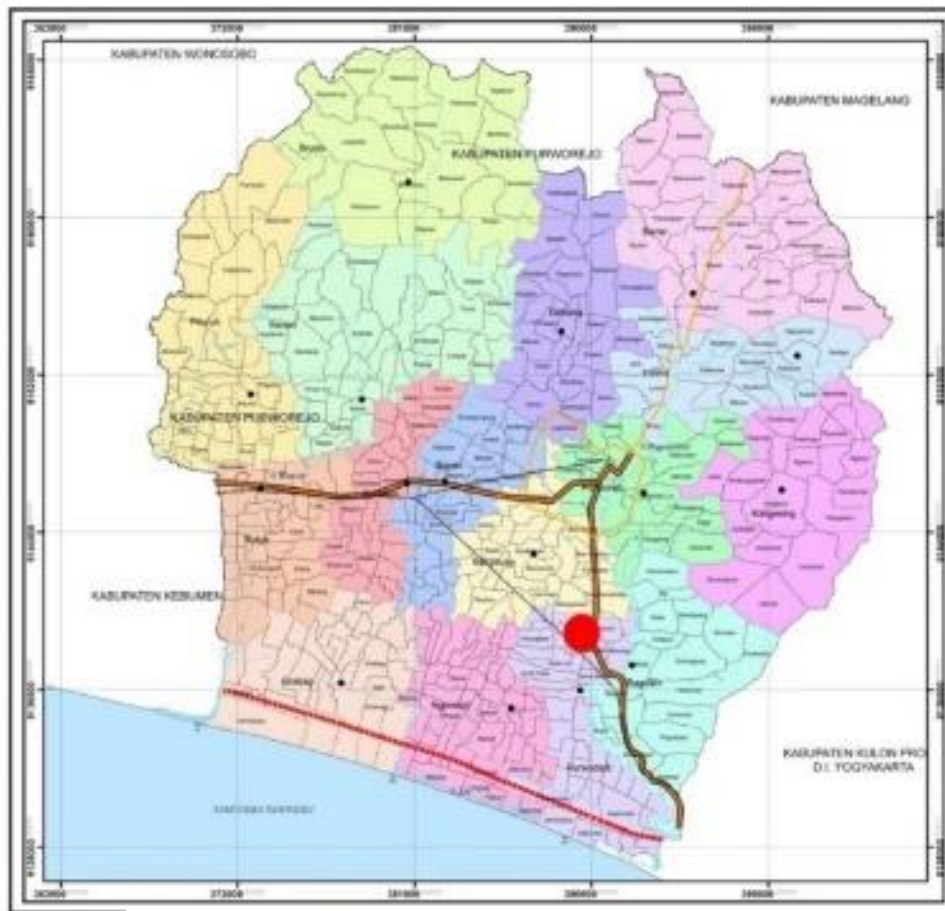

Gambar 1. Lokasi Penelitian.

(Sumber : smeksas.blogspot.com)

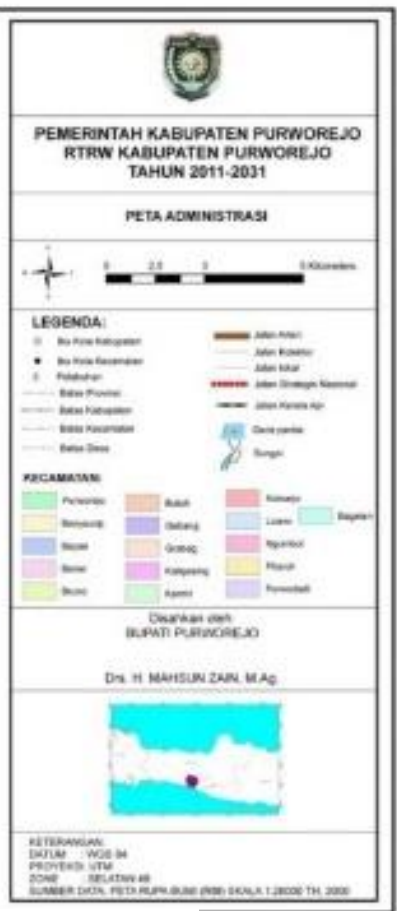

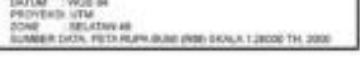


melengkapi data dilakukan studi pustaka.

Untuk memahami pembentukan permukiman emplasemen Pabrik Gula Purworejo, maka diperlukan pemahaman yang berkaitan dengan permukiman secara umum dan perkembangannya, terutama pada masa kolonial serta kaitannya dengan peristiwa Revolusi Industri mengingat kebaradaan permukiman pegawai ini berhubungan dengan bangunan pabrik gula sebagai hasil dari Revolusi Industri.

Pengertian permukiman dalam Kamus Besar Bahasa Indonesia adalah daerah tempat bermukim. Dengan pengertian tersebut, suatu daerah dapat dikatakan sebagai permukiman apabila di sana terdapat tempat tinggal orang (Alwi, 2005; 760). Sementara itu, istilah emplasemen berasal dari istilah Belanda, emplacement yang berarti lapangan terbuka yang disediakan untuk kegiatan industri dengan beragam komponen bangunan untuk menunjang kegiatan di dalamnya. Persebaran tempat tinggal dan hubungan-hubungan antar ruang menjadi pusat kajian mengenai permukiman. Tujuan dari kajian tersebut adalah untuk memahami sistem teknologi, sistem sosial, dan sistem ideologi masyarakat masa lalu. Terdapat beberapa tingkatan dalam kajian permukiman, yakni individual building, community layout, dan zonal pattern. Pada tingkat individual building, kajian yang dipelajari adalah persebaran ruangan dan hubungannya dalam satu bangunan. Kemudian pada tingkat community lay-out, hubungan beberapa bangunan dalam satu situ menjadi objek kajiannya. Pada tingkat yang lebih luas, zonal pattern mengkaji pola sebaran dan hubungan antar komunitas pada suatu wilayah guna memahamii struktur sosial, politik, ekonomi, dan teknologi (Fagan, 1991; 167).

Perkembangan permukiman pada masa kolonial dimulai dari dibangunnya kota Batavia oleh VOC. Ciri utama permukiman pada masa itu ialah adanya pemisahan permukiman berdasarkan ras melalui peraturan wijkenstelsel. Pemisahan ras ini disesuaikan dengan pembagian ras yang berlaku di masa itu, yakni orang Belanda atau kulit putih di tingkat paling atas, orang Timur Asing di tingkat menengah, dan orang pribumi di tingkat paling bawah. Pembagian ras ini bertujuan untuk menjaga martabat orang Belanda sebagai penguasa. Kendati peraturan permukiman ras ini telah ditinggalkan pada abad ke-19, akan tetapi dasar pembagian ras dalam susunan wilayah permukiman masih dipertahankan (Soekiman, 2014; 153-154).

Soekiman (2014) menyebutkan ada tiga ciri untuk dapat memahami struktur permukiman kolonial, yaitu budaya, teknologi, dan struktur kekuasaan kolonial. Unsur-unsur permukiman kolonial mencakup alunalun sebagai pusat kota yang dikelilingi oleh bangunan penting seperti masjid, rumah tinggal bupati, rumah pegawai kolonial, dan bangunan pendukung lain. Beberapa unsur tersebut sudah ada sejak masa pra kolonial seperti alun-alun dengan pohon beringin di tengah, masjid di sebelah barat alun-alun, dan kediaman penguasa di sebelah selatan alun-alun. Ketiga unsur tersebut melambangkan menyatunya penguasa kepada Tuhan dan rakyat. Tata permukiman di Jawa pada abad 
ke-19 meliputi tiga jenis. Pertama adalah permukiman orang Eropa dan elite pribumi berupa kompleks rumah tembok berhalaman luas. Kedua adalah permukiman rapat untuk golongan Timur Asing. Ketiga adalah permukiman golongan pribumi berupa rumah kampung beratap ijuk dan berdinding bambu (Soekiman, 2014; 172-173).

Pada tahun 1870, pemerintah kolonial mensahkan Undang-Undang Agraria yang memberi kesempatan untuk para pengusaha Eropa mendirikan usahanya di Nusantara. Hal itu berdampak dengan semakin banyaknya perusahaan perkebunan beserta pabrik-pabrik milik swasta Eropa yang berdiri di berbagai wilayah kabupaten. Dengan demikian semakin banyak pula rumah gedung atau villa yang dibangun di tengah daerah perkebunan atau lereng perbukitan (Soekiman, 2014; 164). Pada awalnya, rumah-rumah tersebut dibuat dari bahan alami seperti bambu yang tidak awet. Pemilihan bahan bangunan yang masih tidak awet dikarenakan mereka, para pekerja Eropa di perkebunan, merupakan perantau dari Eropa, dimana mereka menjadikan Nusantara sebagai tempat mereka mengumpulkan kekayaan dan mereka akan kembali ke Eropa bila kekayaan sudah terkumpul. Oleh karena mereka tidak berniat menetap lama di Nusantara, maka mereka mendirikan rumah dengan bahan yang sederhana (Wertheim, 1993; 274).

Saat beberapa perusahaanperusahaan swasta di HindiaBelanda mulai didirikan, pada saat yang sama di Eropa, Revolusi Industri sedang mencapai masa puncaknya. Revolusi Industri rupanya memberi pengaruh pada pembentukan sebuah permukiman. Sebelum terjadi Revolusi Industri, para pekerja masih dapat bertemu dengan majikannya karena pada masa itu lokasi pabrik masih menyatu atau tidak jauh dari tempat tinggal pemilik. Peningkatan produksi berdampak dengan membesarnya ukuran pabrik dan meningkatnya kebutuhan tenaga kerja. Akhirnya pemilik pabrik memindahkan pabriknya ke tempat yang terpisah. Karena itu, para majikan samasekali tidak bertemu dengan pekerjanya dengan anggapan bahwa kehidupan para pekerja adalah tanggung jawab pekerja tersebut (Burchell, 1984; 76). Banyak para pekerja yang tinggal di sembarang tempat selama mereka masih mampu membayarnya dan karena upah pekerja saat itu terbilang rendah, maka seringkali mereka tinggal di tempat dengan kondisi yang buruk. Buruknya kehidupan para buruh menjadi landasan munculnya gerakan buruh yang seringkali menggelar aksi mogok kerja. Aksi tersebut berdampak terganggunya kegiatan produksi yang merugikan pemilik pabrik. Keadaan tersebut mendorong beberapa pemilik pabrik untuk memperbaiki kondisi para pekerja dengan menyediakan permukiman yang layak. Ketika semakin banyak kegiatan di sekitar pabrik, maka lahirlah permukiman baru seperti Saltaire dan New Lanark di Inggris dan Cresppi d'Adda di Italia. Karakteristik yang tampak pada sebuah permukiman industri antara lain permukiman pekerja di sekitar pabrik dan sarana lain yang disediakan untuk para pekerja seperti taman, tempat hiburan, klinik, dan sekolah. Konsep permukiman pekerja dibuat dengan tujuan untuk 
mengembalikan manusia pada lingkungan permukiman yang manusiawi; mengembalikan hubungan erat antara manusia dengan lingkungan; serta meningkatkan kualitas kehidupan secara bermasyarakat dan ekonomis (Burchell, 1984; 77-78).

\section{HASIL PENELITIAN}

\section{Sejarah Singkat Pabrik Gula Purworejo}

Saat PG Purworejo dibangun, wilayah tempat pabrik gula tersebut berada di Distrik Purwodadi, Afdeeling Poerworedjo. Pabrik gula Purworejo mulai dibangun tahun 1910an dengan biaya pembangunannya sebesar 3.5 juta gulden. Pembangunan tersebut dibiayai oleh dua pengusaha Belanda, Van Musschrenboek dan Van der Wijk.

Emplasemen pabrik gula dibangun oleh biro Technisch Bureau
E.Rombout di lahan persawahan yang terletak di antara jalur kereta Purworejo-Kutoarjo dan jalan raya Purworejo-Yogyakarta. Dengan luas lahan sekitar 1.750 hektar, PG Purworejo menjadi yang terbesar di Jawa Tengah dan terbesar kedua di Jawa setelah PG Jatiroto di Jawa Timur (Anonim, 1910; 120). Tebu untuk PG Purworejo diambil dari perkebunan tebu yang tanahnya disewa dari penduduk lokal. Untuk mempermudah pengangkutan tebu, PG Purworejo memiliki jaringan kereta lori sepanjang 184 kilometer dan lokomotif sebanyak 17 buah serta gerbong pengangkut tebu sebanyak 1216 buah. Manajemen PG Purworejo dijalankan oleh 37 personel (Knight, 2013; 110-111).

PG Purworejo akhirnya ditutup pada tahun 1933 menyusul terjadinya krisis ekonomi atau malaise (Knight, 2013; 110-111). Sepeninggal PG Purworejo, bangunan pabrik dibongkar dan sebagian besar tanah PG Purworejo dibeli oleh seorang

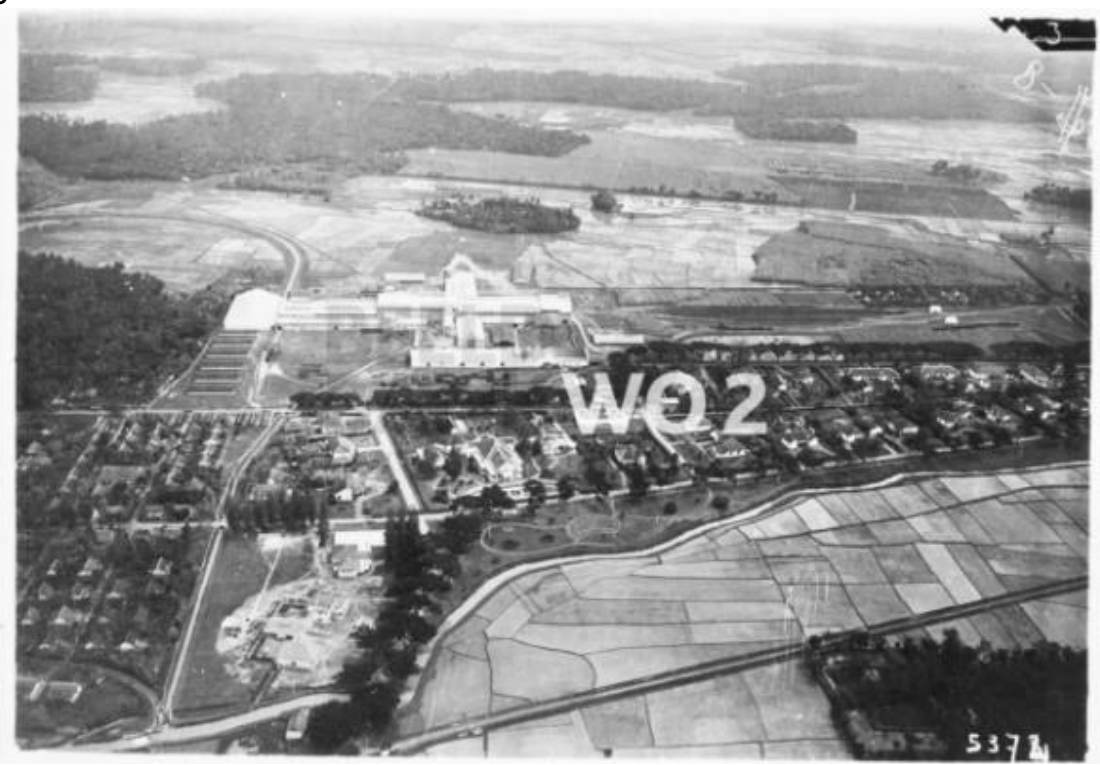

Gambar 1. Emplasemen Pabrik Gula Purworejo tahun 1920an.

Foto menghadap ke arah barat

(Sumber : beeldbankwo2.nl) 
Belanda bernama Johannes Cornelis Suzenaar. Sementara tanah bekas perumahan pegawai dibeli Van Mook untuk dijadikan lahan peternakan sapi. Pada zaman Jepang, bekas rumah kepala pabrik dibongkar untuk dijadikan pabrik beras. Sementara sebagian besar rumah pegawai dibongkar dan menyisakan satu rumah yang pada tahun 1941 dibeli oleh pensiunan pegawai tambang emas di Bengkulu bernama Raden Tjokropawiro. Rumah tersebut sampai sekarang masih terawat baik dan dihuni oleh keluarga Raden Tjokropawiro (wawancara dengan Bapak Bambang).

\section{Gambaran Permukiman Emplasemen}

Secara administratif, Emplasemen PG Purworejo berada di wilayah Desa Plandi, Kecamatan Purwodadi, Kabupaten Purworejo dengan koordinat $7^{0} 789$ ' 667" LS, $109^{\circ}$ 994' 899" BT. Berjarak 320 meter dari emplasemen pabrik, terdapat jalan raya Purworejo-
Yogyakarta. Berdasarkan data peta dan foto lama, emplasemen PG Purworejo berbatasan dengan sawah di sebelah barat, dengan perkampungan di sebelah selatan dan utara dan saluran air di sebelah timur. Secara keseluruhan, emplasemen PG Purworejo dibagi menjadi dua, yakni pabrik pengolahan dan emplasemen lori di barat berada permukiman pegawai di sebelah timur (Lihat gambar 2).

Seperti yang terlihat pada foto lama, di samping utara jalan masuk ke pabrik, terdapat rumah administrateur atau kepala pabrik (Lihat gambar 3). Rumah ini menghadap ke arah timur. Masih satu blok dengan rumah administrateur, di sebelah utara terdapat kantor adminstrasi (Lihat gambar 5) dan societeit (Lihat gambar 4). Sementara di sebelah barat ada lapangan tenis. Kemudian di sebelah utara rumah dinas administrateur , terdapat deretan rumah pegawai sebanyak 15 buah

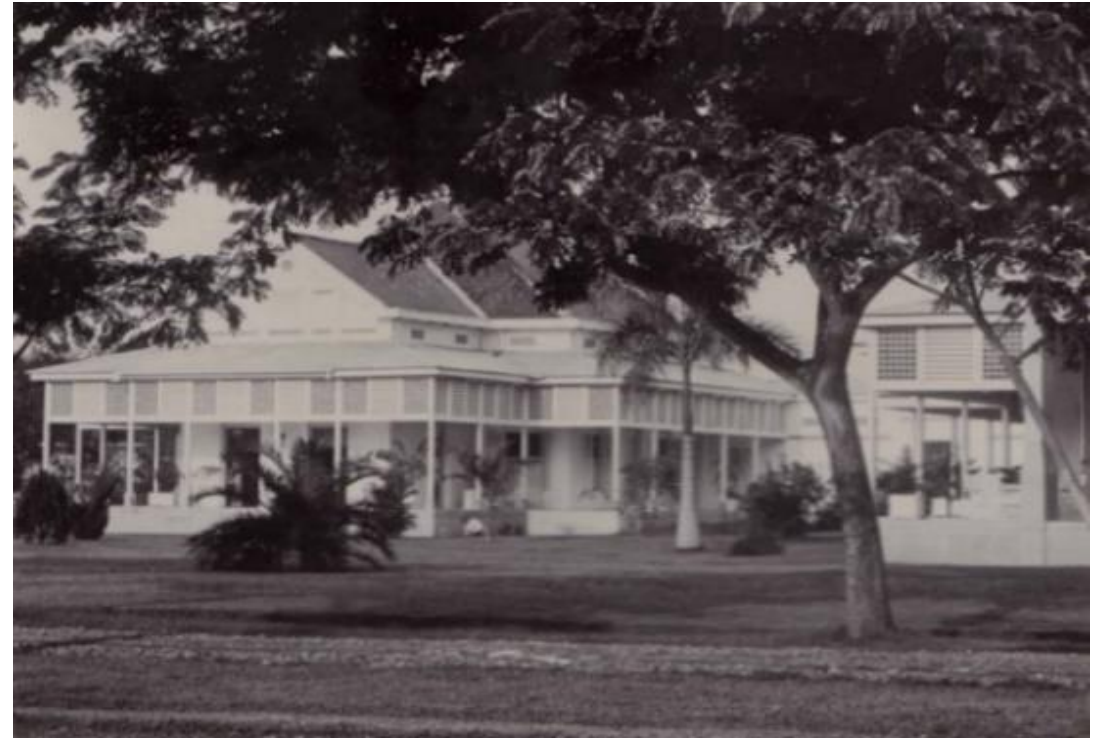

Gambar 2. Rumah dinas administrateur PG Purworejo tahun 1920an (Sumber : collectie.wereldculturen.nl) 


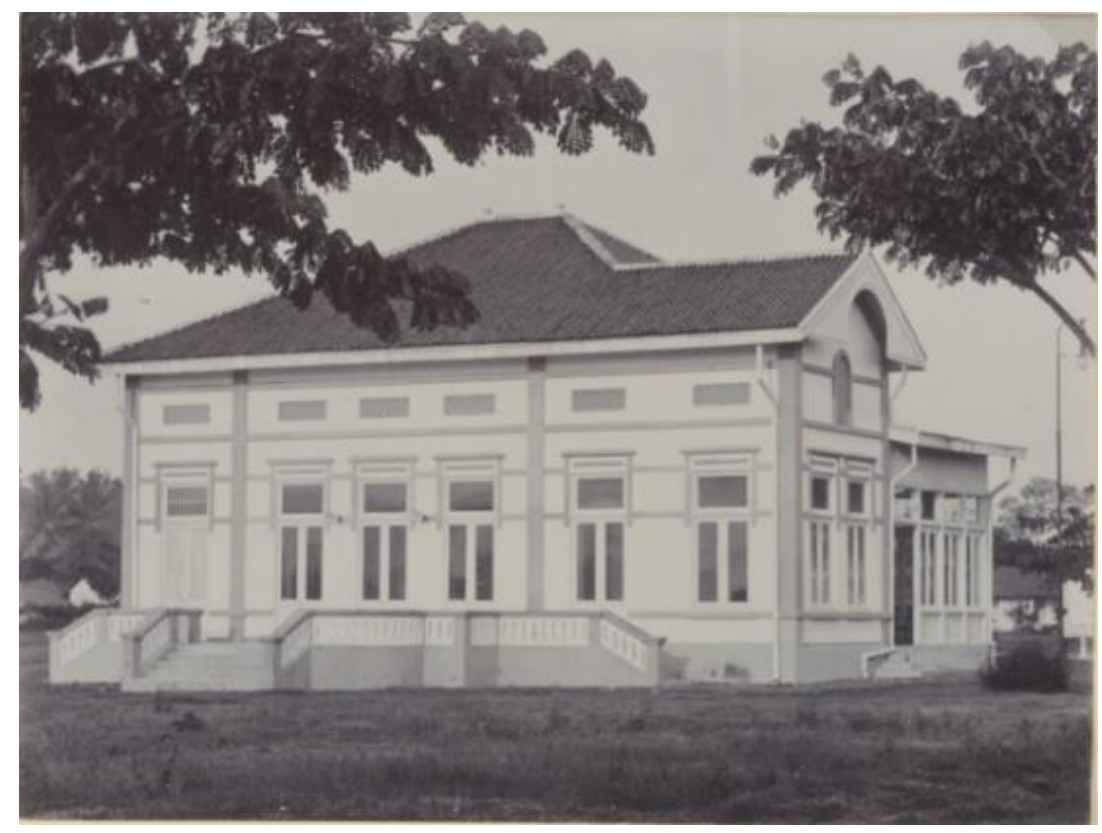

Gambar 4. Gedung societeit PG Purworejo

(Sumber : collectie.wereldculturen.nl)

dengan 5 bangunan berupa rumah kopel (dua rumah dalam satu atap).

Selanjutnya di selatan rumah administrateur terdapat 6 bangunan rumah. Di selatan 6 rumah ini, terdapat 47 rumah beratap kampung dengan ukuran yang lebih kecil. Di sebelah timur rumah administrateur, terdapat sebuah taman (Lihat gambar 2). Keadaan emplasemen PG Purworejo, bangunan pabrik saat ini sudah hancur dan tinggal tersisa

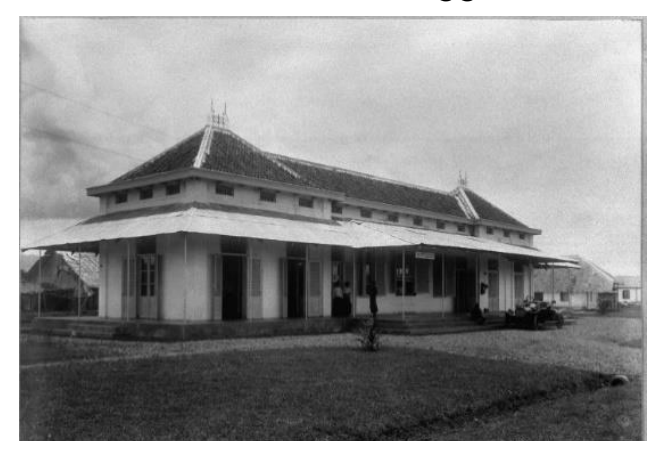

Gambar 3. Kantor administrasi PG Purworejo

(Sumber : colonialarchitecture.eu) struktur pondasi. Sementara itu di permukiman pegawai pabrik, bangunan rumah pegawai sudah hancur dan sebagian besar sudah menjadi pabrik kayu lapis. Bangunan lain seperti soceiteit dan kantor tinggal struktur pondasi di tengah sawah. Sementara taman sekarang sudah berubah menjadi sawah. Hanya tinggal satu bangunan dari permukiman emplasemen $P G$ Purworejo yang masih tersisa, yaitu rumah yang dahulu dibeli oleh Raden Tjokoropawiro pada tahun 1941 (Lihat gambar 8). Saat ini, rumah tersebut dihuni oleh Bapak Bambang yang masih keturunan dari Raden Tjokropawiro. Rumah ini memiliki denah persegi menghadap ke timur. Letak rumah ini berada di ujung timur dari emplasemen PG Purworejo. 


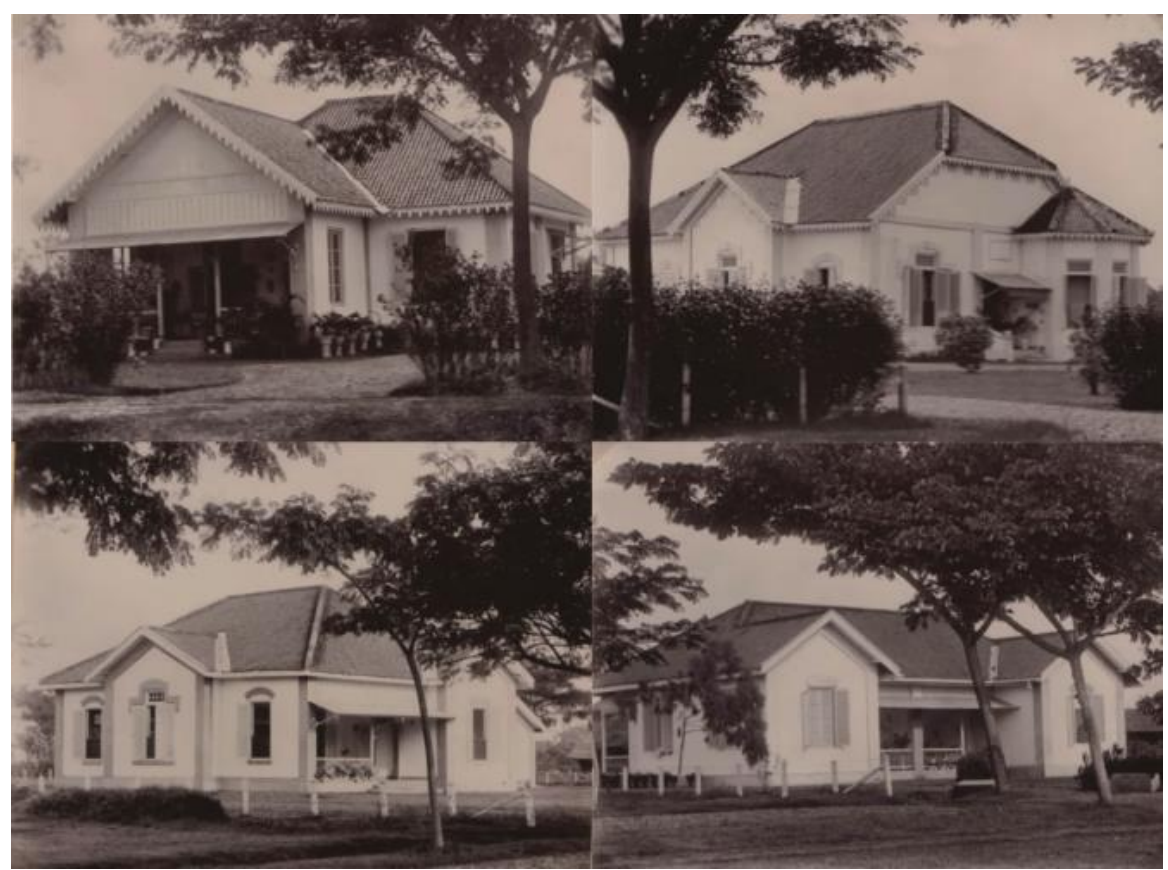

Gambar 6. Rumah pegawai menengah PG Purworejo tahun 1920an (Sumber : collectie.wereldculturen.n/)

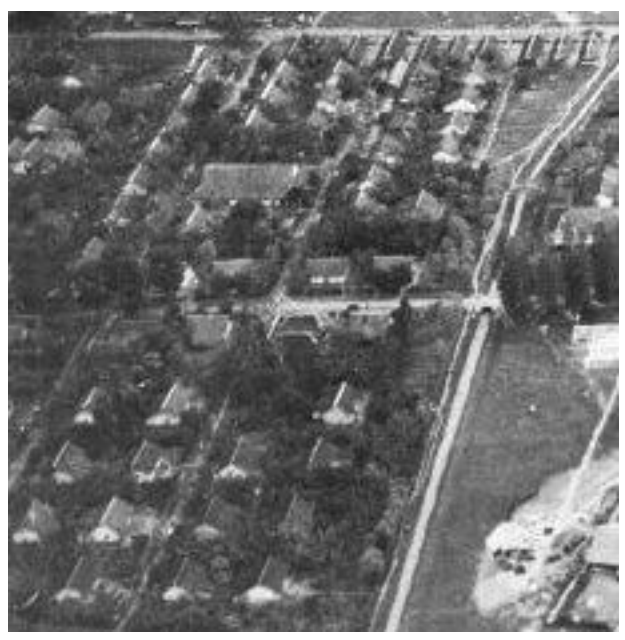

Gambar 5. Kompleks perumahan pegawai pribumi

(Sumber : beeldbankwo2.nl)

\section{DISKUSI DAN PEMBAHASAN}

Kemunculan usaha perkebunan di Hindia-Belanda berawal dari praktik tanam paksa yang diberlakukan sejak tahun 1830. Pada

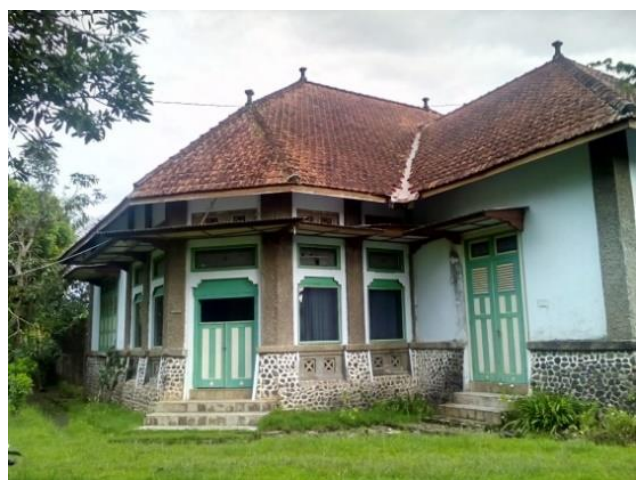

Gambar 8. Satu-satunya rumah dinas PG Purworejo yang masih tersisa (Sumber: Dokumentasi penulis tahun 2017)

masa itu, pemerintah kolonial sedang mengalami krisis keuangan pasca revolusi Belgia dan Perang Jawa. Gubernur Jenderal Hindia-Belanda, Johannes Van den Bosch kemudian memperkenalkan sistem tanam paksa atau cultuurstelsel. Dalam sistem tersebut, seperlima dari tanah penduduk akan ditanami dengan 
tanaman yang ditentukan oleh pemerintah kolonial seperti tebu, nila, kopi, tembakau, dan teh. Sistem tersebut membawa keuntungan besar bagi pemerintah kolonial namun pada praktiknya terjadi penyimpangan seperti tanah yang ditanami dapat lebih dari seperlima lahan. Praktik tanam paksa secara resmi dihapuskan dengan diberlakukannya Undan-Undang Agraria 1870. Undang-Undang tersebut memberikan kesempatan bagi para pemodal swasta untuk membuka usaha perkebunan di Hindia-Belanda namun dengan catatan mereka tidak dapat memiliki tanah dan sebagai gantinya, mereka boleh menyewa tanah kepada petani lokal dalam jangka waktu tertentu (Cribb dan Kahin, 2012; 537-538).

Salah satu usaha perkebunan yang paling diminati adalah perkebunan tebu yang kemudian dilengkapi dengan industri gula. Industri tersebut awalnya dimonopoli oleh pemerintah, namun sejak diberlakukannya Undang-Undang Agraria, industri gula akhirnya banyak dipegang oleh perusahaan swasta yang didirikan baik oleh orang Eropa ataupun orang Tionghoa. Wilayah dataran rendah adalah lokasi yang sesuai untuk perkebunan tebu dan biasanya berada dekat dengan permukiman agar mudah mencari buruh. Selama musim tanam dari bulan April hingga akhir Juli dan musim panen pada tahun berikutnya dari bulan Mei hingga Oktober, para buruh kasar yang seluruhnya adalah orang pribumi dilibatkan. Dari proses penanaman tebu hingga penggilingan, kegiatan buruh tersebut diawasi oleh orang Eropa dalam pengawasan ketat (Wertheim, 1993; 283). Selain bertugas mengawasi, orang-orang Eropa tersebut juga memilliki keahlian tertentu untuk menjalankan pabrik (Stroomberg, 2018; 187).

Untuk mendukung proses pengawasan, maka digunakan konsep panopticon. Panopticon, pada awalnya adalah bangunan penjara yang dirancang oleh filsuf Inggris, Jeremy Betham, pada tahun 1785. Ciri dari penjara panopticon adalah penjara berbentuk melingkar dan di tengah-tengahnya terdapat menara pengawas. Konsep penjara panopticon kemudian dikembangkan oleh filsuf Michael Foucalut sebagai suatu model pengawasan dan pendisiplinan masyarakat. Pada industri gula di Jawa, konsep panopticon diwujudkan dalam bentuk pemisahan ruang antara ruang untuk pimpinan pabrik dalam bentuk rumah dinas dan ruang untuk buruh berupa pabrik. Adanya rumah pimpinan pabrik yang berada di dekat pabrik menciptakan perasaan selalu terawasi walau tanpa kehadiran orang Belanda pada rumah tersebut (Inagurasi, 2010;123).

Di lingkungan sosial pabrik gula, administrateur atau kepala pabrik berada di tingkat paling atas. Mengawasi proses penanaman, penggilingan, pembukuan, pengangkutan, dan segala urusan internal pabrik secara keseluruhan adalah tanggung jawab seorang administrateur. Rumitnya industri gula dari proses penanaman hingga pengolahan menjadi gula membutuhkan pegawai yang memiliki keahlian tertentu seperti zinder, chemicer, dan masinis yang diambil dari orang Eropa yang telah mendapat pendidikan di bidang tersebut. Dalam lingkungan pabrik gula, kedudukan mereka setingkat di 


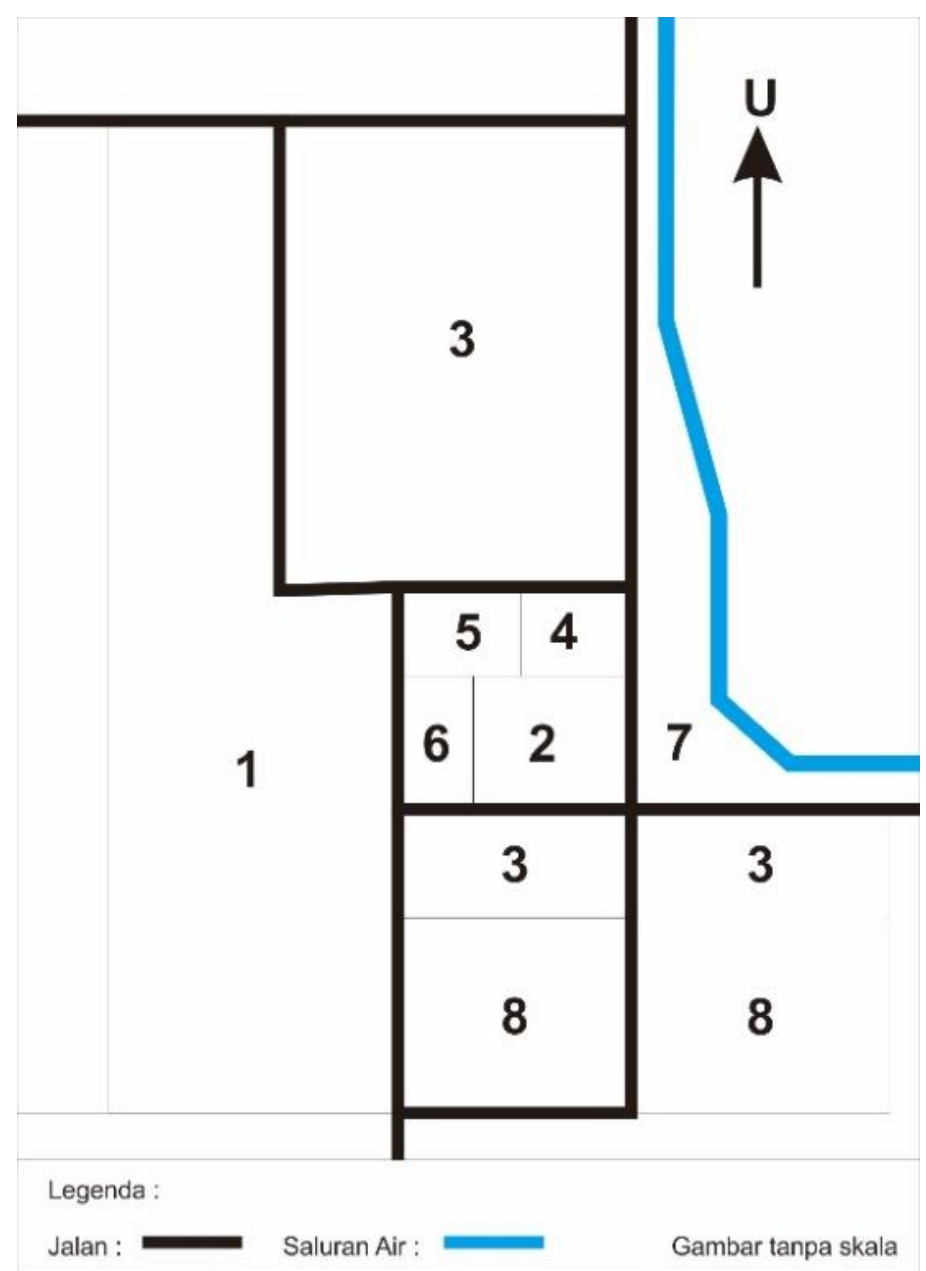

Gambar 9. Denah emplasemen PG Purworejo. Keterangan 1 : Pabrik pengolahan.

2 : Rumah dinas administrateur.

3 : Rumah dinas pegawai ahli. 4 : Societeit.

5 : Kantor administrasi. 6 : Lapangan tenis.

7 : Taman. 8 : Rumah pegawai pribumi

(Sumber: Dibuat penulis berdasarkan foto gambar 1)

bawah administrateur. Zinder bertugas untuk mengawasi tanaman tebu yang sedang ditanam di ladang. Tugas zinder di lapangan antara lain mengukur tanah, mengawasi irigasi, pembibitan, pemupukan, pembasmian hama, pemanenan dan pengangkutan. Chemicer adalah ahli gula yang memiliki tugas untuk memastikan jika proses pengolahan menghasilkan gula yang berkualitas.
Setelah gula diproses melalui proses pemurnian, penguapan, pemasakan, pemutaran, dan pengkristalan, sampel gula akan dibawa chemicer ke laboratorium untuk menentukan kualitas gula. Oleh karena itu, selain bekerja di pabrik, chemicer juga bekerja di laboratorium sehingga chemicer harus da pat membagi waktunya antara berada di pabrik dengan di laboratorium. Masinis 
bertanggung jawab pada pemeliharaan mesin, baik mesin pengolahan ataupun lokomotif yang dipakai untuk membawa tebu ke pabrik. Masinis biasanya dibantu oleh dua orang asisten. Tugas masinis selama musim giling adalah yang paling vital karena kerusakan mesin berdampak pada proses produksi secara keseluruhan. Karena itulah masinis harus siaga selama 24 jam mengingat proses penggilingan berlangsung sepanjang hari secara terus menerus. Golongan paling bawah adalah pegawai pribumi. Ada dua macam pekerjaan, yakni di lapangan dan di pabrik. Selama bekerja, mereka berada di bawah pengawasan zinder, chemicer, dan masinis (Wiseman, 2001; 398-401).

Sebagaimana pabrik gula lain di Jawa, PG Purworejo selama musim giling terus melakukan penggilingan sepanjang hari. Dalam sehari pekerjaan di pabrik dibagi menjadi dua shift, yakni shift malam dan siang yang setiap shift mencapai 12 jam (Wertheim, 1993 ; 280). Karena tuntutan pekerajaan, maka para pegawai harus selalu berada di dekat tempat kerjanya. Untuk memudahkan pergerakan, maka dipakailah konsep permukiman industri, yakni permukiman pegawai dibangun di dekat pabrik. Singkatnya jarak antara rumah pegawai dengan lokasi kerja juga membantu pemilik pabrik untuk menghemat ongkos transportasi pegawai (van Moll dan Lugten, 1916; 9). Selain untuk mempermudah pergerakan menuju pabrik, konsep ini juga memberi kemudahan komunikasi di antar pegawai (Dhani, 2010 ; 86).

Pembangunan permukiman di pabrik gula, menurut van Moll dan Lugten (1916) juga harus diikuti dengan sarana hiburan karena kehidupan pabrik gula cenderung monoton akibat letaknya yang jauh dari pusat keramaian. Oleh karena itu disediakan sarana hiburan berupa soceiteit, lapangan tenis dan taman terbuka. Hal tersebut merupakan upaya pemilik pabrik dalam memenuhi kebutuhan jasmani dan rohani pegawainya, sehingga diharapkan produktivitas pabrik bisa berkembang karena para pegawai bekerja dengan semangat dan dedikasi tinggi.

Perbedaan

hierarki mempengaruhi ukuran dan bentuk rumah. Administrateur sebagai jabatan tertinggi di lingkungan pabrik memiliki rumah paling megah serta halamannya paling luas (Inagurasi, 2010; 54). Berikutnya adalah rumah pegawai menengah yang ukurannya sedikit lebih kecil, namun masih memiliki hiasan dan setiap rumah memiliki bentuk yang berbeda. Rumah yang paling kecil dan sederhana adalah rumah pegawai pribumi yang seragam bentuknya.

$P G$ Purworejo dibangun pada
lahan yang belum ada permukimannya. Oleh sebab itu dibuatlah pola jalan yang benarbenar baru. Penempatan rumah pegawai menengah dibuat sejajar dengan emplasemen pabrik yang membujur ke utara. Kemudian rumah pegawai bawah diletakan di selatan, dekat dengan perkampungan penduduk setempat. Sementara rumah dinas administrateur diletakan di tengah permukiman. Permukiman baru dengan pola jalan yang tertata mulai dibuka. Pembangunan PG Purworejo bersamaan dengan upaya pemerintah kotapraja di HindiaBelanda untuk melakukan pemekaran wilayah. Pemerintah 
kotapraja membuka lahan permukiman baru yang berada di pinggir kota. Sebelum permukiman dibuka, sudah direncakan pengaturan jalan dan pembagian kaveling lahan. Pembangunan permukiman baru ini didasarkan pada konsep kota taman yang diperkenalkan oleh Ebenezer Howard. Rumah-rumah dibangun pada kaveling yang telah disediakan. Model dasar setiap rumah adalah rumah tunggal satu lantai yang dikelilingi halaman terbuka. Di tengah permukiman disediakan taman terbuka dan dilengkapi dengan sarana umum seperti sekolah, gereja, atau societeit. Pengaturan permukiman ini tidak lagi memakai konsep pengaturan kota tradisional karena unsur seperti masjid, alunalun, dan kediaman penguasa tidak lagi disertakan. Aspek kenyaman dan estetika lebih ditekankan pada permukiman baru ini sehingga pengaturannya murni didasarkan pada pertimbangan praktis (Passchier,2002; 124).

Dalam pengaturannya, terlihat ada upaya segregasi yang diterapkan oleh pemilik pabrik. Konsep segregasi berdasarkan ras sebenarnya sudah ada sejak masa kolonial awal dan dihapus pada akhir abad ke-19. Meskipun pembagian permukiman berdasarkan ras sudah ditiadakan, namun bukan berarti praktik di lapangan berakhir. Hal tersebut dapat dilihat pada pembagian permukiman untuk pegawai Eropa dan pegawai pribumi. Pegawai Eropa tinggal di sebelah utara jalan masuk ke pabrik, sementara pegawai pribumi tinggal di sebelah selatan jalan (lihat gambar 9).

Sebagai pemimpin tertinggi di lingkungan sosial pabrik gula, peletakan rumah administrateur diletakan di tempat yang strategis dan mudah dilihat, yakni berada di tengah empalsemen. Segala fasilitas untuk pegawai pabrik dibangun di dekat rumah administrateur seperti kantor, taman, sosieteit, dan lapangan tenis dibangun di dekat tempat tinggal administrateur (lihat gambar 9). Peletakannya yang berada di tengah lingkungan emplasemen juga dimaksudkan untuk sarana pengawasan sebagai strategi untuk mengontrol kedisiplinan buruh. Menurut Inagurasi, rumah adiministrateur selain memiliki fungsi sebagai tempat tinggal juga memiliki fungsi lain sebagai sarana pengawasan mengingat peran seorang administrateur sebagai seorang pemimpin di pabrik gula yang memiliki bawahan. Penempatan bangunan adalah salah satu strategi untuk meningkatkan pengawasan (Inagurasi, 2010; 120). Arah hadap yang dihadapkan ke arah timur juga dimaksudkan agar administrateur bisa menikmati pemandangan perbukitan Menoreh yang berada di timur. Van Moll dan Lugten (1916) menjelaskan bahwa pemandangan adalah faktor penting dalam menentukan orientasi rumah tinggal.

Untuk rumah pegawai ahli setingkat di bawah administrateur, juga dibangun rumah pegawai Eropa dibuat dalam bentuk yang beragam dan diberi beberapa hiasan untuk menambah keindahan meskipun ukurannya sedikit kecil dibanding rumah administrateur (Lihat gambar 6). Pengelompokan permukiman pegawai Eropa berada di sebelah utara rumah administrateur. Permukiman Eropa juga diberi sarana hiburan seperti sosieteit dan lapangan tenis. Di sosieteit, orang 
Eropa dapat mencari hiburan seperti minum minuman keras, berdansa, bermain bilyar, bermain kartu dan sebagainya. Letaknya yang berada di dekat permukiman orang Eropa dimaksudkan agar hiburan tersebut hanya dapat dinikmati oleh golongan orang Eropa. Pemisahan letak rumah pegawai Eropa dengan pegawai pribumi menurut Hari Libra Inagurasi menunjukan bahwa sebagai golongan atas, pegawai Eropa membatasi interaksi dengan pegawai pribumi karena orang-orang pribumi dipandang rendah oleh orang Eropa (Inagurasi, 2010; 114).

Sementara rumah pegawai pribumi dibuat secara seragam, ukuran lebih kecil dan minim hiasan, semata-mata dibangun untuk memenuhi kebutuhan tempat tinggal (Lihat gambar 7). Dibanding permukiman untuk pegawai Eropa, permukiman buruh pribumi baru muncul belakangan. Sebelum tahun 1910, pemilik pabrik biasanya tidak menyediakan tempat tinggal untuk buruh pribumi. Mereka biasanya tinggal di dekat perkampungan yang sudah ada penduduknya. Namun setelah terjadi wabah pes, atas himbauan Tillema, maka pemilik pabrik didorong untuk memperhatikan kesejahteraan buruh karena jika buruh mudah sakit, maka hal tersebut berdampak pada produktivitas pabrik. Oleh karena itu dibangunlah permukiman buruh yang lebih bersih dan lebih sehat (Soekiman, 2014; 177).

\section{KESIMPULAN}

Walau PG Purworejo telah lama hilang, namun melalui data sejarah berupa literatur dan foto lama serta tinggalan yang masih tersisa di lapangan dapat direkonstruksi bagaimana permukiman emplasemen PG Purworejo dari dibangun pada tahun 1910an hingga ditutup pada tahun 1930. Emplasemen PG Purworejo dibangun dengan mengikuti konsep permukiman industri. Ciri dari konsep permukiman industri adalah adalah kegiatan industri sebagai kegiatan utama sementara kegiatan lain bersifat sebagai pendukung saja. Pemilihan konsep tersebut lebih menekankan aspek fungsional, yakni untuk mempermudah kerja industri dan interaksi antar karyawan. Salah satu ciri dari konsep permukiman industri adalah peletakan permukiman pekerja yang berada di dekat perindustrian dengan sarana lain untuk pekerja di dalamnya. Namun demikian, terdapat perbedaan bentuk pada konsep permukiman industri di Eropa dengan di PG Purworejo. Jika permukiman industri di Eropa berbentuk rumah gandeng bertingkat, maka permukiman emplasemen PG Purworejo berupa rumah tunggal satu lantai yang dikelilingi halaman terbuka. Sarana yang dibangun untuk pekerja meliputi taman, sosieteit, dan lapangan tenis. Berdasarkan rekonstruksi pada peta, permukiman PG Purworejo selain menggunakan konsep permukiman industri, juga mengikuti konsep kota kolonial. Hal tersebut ditandai dengan pemisahan permukiman pegawai Eropa yang ada di sebelah utara dengan pegawai pribumi yang ada di sebelah selatan pabrik. Pegawai Eropa disediakan rumah yang besar dan indah yang dikelompokkan terpisah dengan permukiman orang pribumi yang diberi rumah yang ukurannya kecil dan sederhana. Untuk mendisiplinkan para pegawai, 
administrateur selaku pemimpin di lingkungan pabrik gula diberi tempat tinggal yang letaknya strategis sehingga pengawasan menjadi mudah. 


\section{DAFTAR PUSTAKA}

Alwi, Hasan. 2005. Kamus Besar Bahasa Indonesia. Jakarta : Balai Pustaka.

Becking. 1923. Eene Beschrijving van Poerworedjo en Omstreken. Dalam Indie, geilustreerd weekblad voor Nederland en Kolonien no.47 tanggal 21 Februari 1923 : halaman 70.

Burchell, Samuel. 1984. Abad Kemajuan. Jakarta : Tira Pustaka.

Carneiro, Robert L. 1970. A Theory of the Origin of the State, dalam Science, Vol 169, halaman 733-738.

Cribb, Robert dan Kahin, Audrey. 2012. Kamus Sejarah Indonesia. Depok : Komunitas Bambu.

Dhani, Rizal. 2010. “ Situs Pabrik Gula Sewugalur ( 1889 - 1930 ) ; Tinjauan terhadap Latar Belakang Pemilihan Lokasi dan Pengaruh Keberadaanya terhadap Permukiman Kolonial di Sekitarnya “. Skripsi. Yogyakarta : Fakultas IImu Budaya Universitas Gadjah Mada.

Fagan, Brian. M. 1991. Archaeology A Brief Introduction. New York : HarperCollins Publisher.

Inagurasi, Hari Libra. 2010. "Pabrik Gula Cepiring di Kendal Jawa Tengah Tahun 1835-1930, Sebuah Studi Arkeologi Industri “. Tesis. Depok : Fakultas IImu Budaya Universitas Indonesia.

Knight, G. Roger. 2013. Commodities and Colonialism, The Story of Big Sugar in Indonesia, 1880-1942. Boston : Brill.

Knight, G Roger. 1999. "The Visible Hand in Tempo Doeloe : The Culture of Management and the Organization of Business in Java's Colonial Industry ". Dalam Journal of Southeast Asian Studies Vol. 30, No. 1. Halaman 74-98. Singapura : Departement of History, National University of Singapore.

Passchier, Cor. 2002. "Kota Taman dan Bungalo Pinggiran Kota". Dalam Indonesia Heritage ; Architecture. 124. Disusun oleh Gunawan Tjahjono Jakarta : Tira Pustaka.

Sari, Putri Chomala. 2012. "Pengaruh Industri Tambang Batubara terhadap Perkembangan Kota Sawahlunto (1891-1935)". Skripsi. Yogyakarta : Fakultas IImu Budaya Universitas Gadjah Mada.

Soekiman, Djoko. 2014. Kebudayaan Indis. Depok : Komunitas Bambu.

Stroomberg, J. 2018. Hindia-Belanda 1930. Yogyakarta : IRCiSoD.

Sulastri, Sri Budi. 1998. "Pola Tata Ruang Kompleks Pabrik Gula Colomadu". Skripsi. Yogyakarta : Fakultas Ilmu Budaya Unversitas Gadjah Mada. 
Van Moll dan Lugten, C.H. 1916. Projecten van Wooningen voor Suikerondernemingen. Amsterdam : De Bussy.

Wertheim, Wim. F. 1993. :"Condition on Sugar Estates in Colonial Java : Comparation with Deli ".Dalam Journal of Southeast Asian Studies Vol. 24, No. 2. Halaman 268-284. Singapura : Departement of History, National University of Singapore.

Wiseman, Roger. 2001. "Three Crises : Management in The Colonial Java Industry 1880s-1930s “. Tesis. Adelaide : Departement of History University of Adelaide.

\section{DAFTAR NARASUMBER}

$\begin{array}{ll}\text { Nama } & : \text { Bambang } \\ \text { Usia } & : 68 \text { tahun } \\ \text { Pekerjaan } & : \text { Pensiunan } \\ \text { Alamat } & : \text { Desa Plandi, Kecamatan Jenar, Kabupaten Purworejo. }\end{array}$

